\title{
Mannan-binding lectin activates C3 and the alternative complement pathway without involvement of $\mathrm{C} 2$
}

\author{
Barbro Selander, ${ }^{1}$ Ulla Mårtensson, ${ }^{1}$ Andrej Weintraub,,2 Eva Holmström, ${ }^{1}$ Misao Matsushita, ${ }^{3}$ \\ Steffen Thiel, ${ }^{4}$ Jens C. Jensenius, ${ }^{4}$ Lennart Truedsson, ${ }^{1}$ and Anders G. Sjöholm ${ }^{1}$ \\ ${ }^{1}$ Institute of Laboratory Medicine, Section of Microbiology, Immunology, and Glycobiology, Lund University, Lund, Sweden. \\ 2Department of Laboratory Medicine, Division of Clinical Bacteriology, Karolinska Institutet, Karolinska University Hospital, Huddinge, Sweden. \\ ${ }^{3}$ Institute of Glycotechnology and Department of Applied Biochemistry, Tokai University, Hiratsuka, Japan. \\ ${ }^{4}$ Department of Medical Microbiology and Immunology, University of Aarhus, Aarhus, Denmark.
}

\begin{abstract}
Lectin pathway activation of $\mathrm{C} 3$ is known to involve target recognition by mannan-binding lectin (MBL) or ficolins and generation of classical pathway C3 convertase via cleavage of C4 and C2 by MBL-associated serine protease 2 (MASP-2). We investigated C3 activation in C2-deficient human sera and in sera with other defined defects of complement to assess other mechanisms through which MBL might recruit complement. The capacity of serum to support C3 deposition was examined by ELISA using microtiter plates coated with $O$ antigen-specific oligosaccharides derived from Salmonella typhimurium, S. thompson, and S. enteritidis corresponding to serogroups $\mathrm{B}, \mathrm{C}$, and $\mathrm{D}(\mathrm{BO}, \mathrm{CO}$, and $\mathrm{DO})$. $\mathrm{MBL}$ bound to $\mathrm{CO}$, but not to $\mathrm{BO}$ and $\mathrm{DO}$, and efficiently supported C3 deposition in the absence of C2, C4, or MASP-2. The existence of an MBL-dependent $\mathrm{C} 2$ bypass mechanism for alternative pathway-mediated $\mathrm{C} 3$ activation was clearly demonstrated using $\mathrm{CO}$, solid-phase mannan, and $E$. coli LPS. MASP-1 might contribute, but was not required for C3 deposition in the model used. Independent of MBL, specific antibodies to $\mathrm{CO}$ supported $\mathrm{C} 3$ deposition through classical and alternative pathways. MBL-dependent $\mathrm{C} 2$ bypass activation could be particularly important in various inherited and acquired complement deficiency states.
\end{abstract}

\section{Introduction}

Mannan-binding lectin (MBL; also referred to as mannose-binding lectin) is a $\mathrm{Ca}^{2+}$-dependent lectin belonging to the collectin family of proteins and is an important constituent of innate immunity $(1-3)$. The protein is an oligomer of subunits that each contains 3 identical polypeptide chains with a C-terminal carbohydrate recognition domain, a neck region, a collagenous region, and an $\mathrm{N}$-terminal cystein-rich region. MBL selectively recognizes patterns of sugars such as mannose, $N$-acetylglucosamine, and fucose on microbial surfaces. MBL oligomers form complexes with 3 proteases, MBL-associated serine protease 1 (MASP-1; ref. 4), MASP-2 (5), and MASP-3 (6), and nonenzymatic protein MAp19 (7). Low-order MBL oligomers mainly associate with MASP-1 and MAp19, while higher oligomers associate with MASP-2 and MASP-3 (6). L-ficolin and $\mathrm{H}$-ficolin are 2 other recognition proteins that form complexes with MASPs $(3,8)$. Binding of MBL/MASP or ficolin/MASP complexes to target molecules activates the lectin pathway of complement with recruitment of $\mathrm{C} 3$ and the terminal complement components (C5-C9) $(8,9)$. Thus complement activation can proceed through 3 major pathways, the classical pathway

Nonstandard abbreviations used: B, factor B; BO, polyacrylamide conjugate of Salmonella serogroup B-specific oligosaccharide; C1 INH, C1 inhibitor; C2D:18, $\mathrm{C} 2$-deficient patient 18 ; $\mathrm{C} 4 \mathrm{~b} 2 \mathrm{a}$, classical pathway $\mathrm{C} 3$ convertase; $\mathrm{CO}$, polyacrylamide conjugate of Salmonella serogroup C-specific oligosaccharide; D, factor D; DO, polyacrylamide conjugate of Salmonella serogroup D-specific oligosaccharide; MASP, MBL-associated serine protease; MBL, mannan-binding lectin; $\mathrm{P}$, properdin; PNHS, pooled normal human serum; rMBL, recombinant MBL; VBS,

Veronal-buffered saline.

Conflict of interest: The authors have declared that no conflict of interest exists. Citation for this article: J. Clin. Invest. 116:1425-1434 (2006). doi:10.1172/JCI25982.
$\left(\mathrm{C} 1 \mathrm{qr}_{2} \mathrm{~s}_{2}, \mathrm{C} 4, \mathrm{C} 2\right.$, and $\left.\mathrm{C} 3\right)$, the alternative pathway (C3, factor $\mathrm{B}$ $[\mathrm{B}]$, factor $\mathrm{D}[\mathrm{D}]$, and properdin $[\mathrm{P}])$, and the lectin pathway (10). MASP-1 and MASP-2 are controlled by $\mathrm{C} 1$ inhibitor (C1 INH) and may also be controlled by $\alpha 2$-macroglobulin (11-13).

Complement activation through the lectin pathway is known to involve activation of MASP-2, which then cleaves C4 and C2 with formation of the classical pathway $\mathrm{C} 3$ convertase $(\mathrm{C} 4 \mathrm{~b} 2 \mathrm{a})$ $(5,14)$. Activation of $\mathrm{C} 3$ by $\mathrm{C} 4 \mathrm{~b} 2 \mathrm{a}$ is amplified through recruitment of the alternative pathway (9). A second mechanism for MBL pathway-dependent activation of $\mathrm{C} 3$ and the alternative pathway has been suggested to be based on direct C3 cleavage by MASP-1 (15). However, C3 cleavage by MASP-1 is inefficient, which has cast doubt upon the biological role of a C4b2a-independent mechanism (11-13). The question concerning the existence of a functional MBL-dependent bypass mechanism is of considerable interest and may be clinically relevant in conditions such as C4 and C2 deficiency.

Homozygous deficiencies of C4 and C2 are genetically welldefined immunodeficiency states that predispose to infection and development of immunological disease $(16,17)$. C2 deficiency has an estimated prevalence of about 1 in 20,000 in Western populations (18). Complete C2 deficiency, C2 deficiency type I, is usually caused by a 28-bp deletion of the $\mathrm{C} 2$ gene, while $\mathrm{C} 4$ deficiencies are very rare and have a more heterogeneous genetic background $(16,18)$. Most complement functions in $\mathrm{C} 2$ or C4 deficiency rely on an intact alternative pathway. MBL deficiency, which has a broad, less distinct spectrum of disease associations compared with other complement deficiencies, is remarkably common and has a prevalence of more than $5 \%$ in several populations $(1,3)$. It is caused by homozygosity or compound heterozygosity involving structural gene mutations at 
Table 1

MBL, Anti-CO Ig, B, and P serum concentrations and MBL genotypes

$\begin{array}{lcccccc}\text { Serum } & \begin{array}{c}\text { MBLA } \\ (\mathbf{m g} / \mathbf{l})\end{array} & \begin{array}{c}\text { Anti-CO IgM } \\ (\mathbf{m g} / \mathbf{l})\end{array} & \begin{array}{c}\text { Anti-CO IgG } \\ (\mathbf{m g} / \mathbf{l})\end{array} & \begin{array}{c}\text { MBL } \\ \text { genotype }\end{array} & \begin{array}{c}\mathbf{B}^{\mathbf{3}} \\ (\mathbf{m g} / \mathbf{l})\end{array} & \begin{array}{c}\mathbf{P C} \\ (\mathbf{m g} / \mathbf{l})\end{array} \\ \text { PNHS } & 1.75 & 0.91 & 0.82 & - & 200 & 25 \\ \text { MBLD } & <0.015 & 5.56 & 8.7 & - & 158 & 23 \\ \text { C1qDP- } & <0.015 & 4.1 & 8.3 & - & 150 & <0.5 \\ \text { depleted MBLD } & & & & & & \\ \text { C2D:9 } & 0.44 & 0.28 & <0.05 & \text { AHY/BLY } & 174 & 36 \\ \text { C2D:17 } & 2.72 & 0.48 & <0.05 & \text { AHY/ALX } & 110 & 22 \\ \text { C2D:18 } & 2.69 & 0.41 & <0.05 & \text { AHY/AHY } & 144 & 28 \\ \text { C2D:21 } & 0.051 & <0.1 & <0.05 & A L X / B L Y & 132 & 21 \\ \text { C4D } & 10.0 & 0.23 & <0.05 & \text { AHY/AHY } & 382 & 33 \\ & & & & & & \end{array}$

MBLD, MBL-deficient serum; ${ }^{A}$ Reference interval, 0.1-6.0 mg/l. ${ }^{B}$ Reference interval, 118-308 mg/l. ' Reference interval, 13.5-39 mg/l.

codons 52 ( $D$ allele), 54 ( $B$ allele), or 57 ( $C$ allele) and low expression haplotypes $(L X)$ in the MBL promoter region $(1,19,20)$.

In the present study, the capacity to support $\mathrm{C} 3$ deposition was studied by ELISA in a panel of sera with defined defects of complement function. In the ELISA, surface-adsorbed polyacrylamide-conjugated $\mathrm{O}$ antigen-specific oligosaccharides (21) derived from Salmonella typhimurium (serogroup B), S. thompson (serogroup C), and S. enteritidis (serogroup D) were used as antigens. Complement-activating properties of the 3 oligosaccharides have been previously studied (22), and Salmonella serogroup C has been reported to bind MBL (23). C2 deficiency type I sera (24) were investigated together with MBL-deficient sera and sera with combined C2 and MBL deficiency (25), C4-deficient serum (26), and sera that were specifically depleted of classical and alternative pathway components (27) and of MASPs. The sera were reconstituted with purified proteins in different combinations for selective analysis of complement pathways. Calibrated methods were used for quantitation of antibodies to the Salmonella O antigens (25). The results demonstrated that C3 and the alternative pathway were activated through an MBL-dependent $\mathrm{C} 2$ bypass mechanism. The mechanism may be biologically important and did not appear to require recruitment of MASP-1, MASP-2, and MASP-3. Results
C3 deposition induced by Salmonella O antigen-spe-
cific oligosaccharides. C3 deposition was assessed
in pooled normal human serum (PNHS) and in
serum from C2-deficient patient 18 (C2D:18;
Table 1) using different amounts of polyacryl-
amide conjugate of Salmonella serogroup B-spe-
cific oligosaccharide (BO), C-specific oligosaccha-
ride (CO), and D-specific oligosaccharide (DO)
for coating. At coating doses of 100 and 1,000 ng/
well, the CO antigen gave pronounced C3 depo-
sition in both sera (Figure 1 , A and B). The BO
and DO antigens produced very little C3 deposi-
tion in C2-deficient serum but were moderately active in PNHS. Kinetic C3 deposition experiments with PNHS and the C2-deficient sera C2D:9, C2D:17, and C2D:18 confirmed that $\mathrm{C} 3$ deposition was much more pronounced in the presence of $\mathrm{CO}$ antigen than in the presence of $\mathrm{BO}$ and $\mathrm{DO}$, particularly in C2-deficient serum (Figure 1, C and D).

Requirement of $M B L$ and other recognition molecules. In order to examine MBL binding in our assay system, different dilutions of MBL-sufficient serum were added to wells coated with $\mathrm{BO}, \mathrm{CO}$, or DO followed by measurement of bound MBL. In $\mathrm{Ca}^{2+}$-containing Veronal-buffered saline (VBS), MBL binding to CO was readily detectable at concentrations down to $0.005 \mathrm{mg} / \mathrm{l}$. MBL did not bind to $\mathrm{BO}$ and $\mathrm{DO}$ even at high MBL concentrations $(2 \mathrm{mg} / \mathrm{l})$. Thus MBL bound selectively to the $\mathrm{CO}$ antigen. No MBL binding occurred in the presence of VBS-EDTA (data not shown).

We then examined whether serum supported C3 deposition on $\mathrm{CO}$ antigen without involvement of MBL or Igs. An MBL-deficient serum with high concentrations of IgM and IgG antibodies to $\mathrm{CO}$ (Table 1) efficiently supported C3 deposition, which could be ascribed to classical pathway activation (28). This MBL-deficient serum was depleted of C1q, D, and P (C1qDP-depleted) as well as

\section{Figure 1}

C3 deposition onto wells coated with $\mathrm{O}$ antigen-specific $\mathrm{BO}, \mathrm{CO}$, and DO following incubation in PNHS or C2-deficient serum. (A and B) Influence of the oligosaccharide coating dose. Serum (12.5 $\mu \mathrm{l})$ in VBS $(37.5 \mu \mathrm{l})$ was added to duplicate microtiter plate wells coated with 10,100 , or $1,000 \mathrm{ng}$ of each oligosaccharide and to a control well. All wells were blocked with buffer containing gelatine. Plates were then incubated at $37^{\circ} \mathrm{C}$ for $30 \mathrm{~min}-$ utes. (C and D) Kinetics of C3 deposition in wells coated with oligosaccharide at 1,000 ng/well. C3 deposition was detected with alkaline phosphatase-conjugated rabbit anti-C3c antibodies. Absorbance values were corrected for background. Each panel shows the mean and SEM for 3 separate experiments. Sera from 3 C2-deficient patients were used in the kinetic experiments.
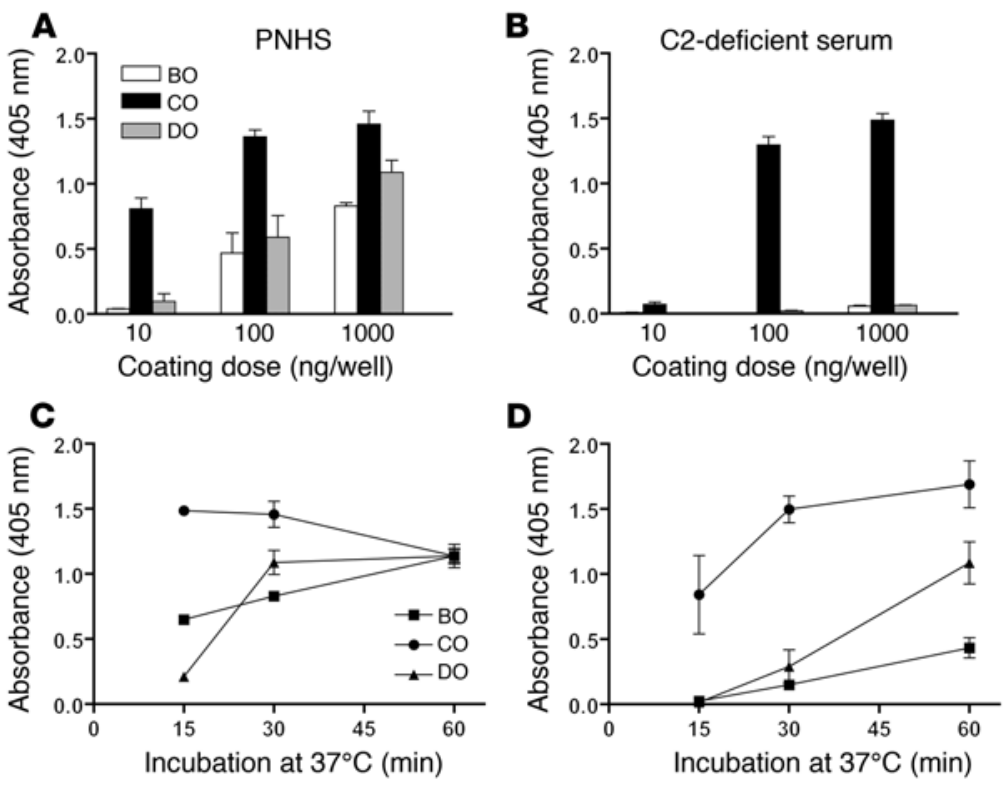


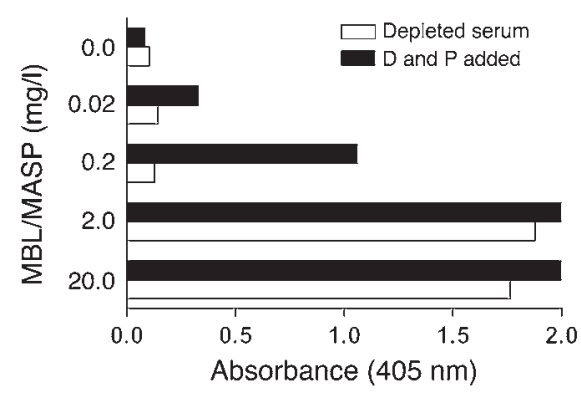

Figure 2

C3 deposition induced by CO antigen (1,000 ng/well) in an MBL-deficient serum that was depleted of C1qDP and Igs. The serum was used at a final concentration of $20 \%$ and was studied with or without reconstitution of the alternative pathway. Reconstitution of undiluted serum with C1q (70 mg/l, not shown) or D (1 mg/l) together with P $(25 \mathrm{mg} / \mathrm{l})$ did not promote $\mathrm{C} 3$ deposition, showing that the $\mathrm{CO}$ antigen did not activate complement in the absence of recognition proteins. Addition of MBL/MASP complexes promoted C3 deposition in a dose-dependent manner; alternative pathway-mediated amplification was evident at moderately low MBL/MASP concentrations but was not required at high MBL/MASP concentrations. C3 deposition was measured after 60 minutes at $37^{\circ} \mathrm{C}$. The experiment was performed in duplicate and was repeated once with similar results.

Igs (see Methods). CO antigen did not induce C3 deposition when the alternative pathway was reconstituted by addition of $\mathrm{D}$ and $\mathrm{P}$ in the absence of MBL and Igs (Figure 2). Moreover, addition of $\mathrm{C} 1 \mathrm{q}$ in different combinations had no effect (data not shown). Thus specific recognition molecules were necessary.

With addition of MBL/MASP to the serum used, lectin pathway activation resulting in $\mathrm{C} 3$ deposition could be mediated through $\mathrm{C} 4 \mathrm{~b} 2 \mathrm{a}$ as well as through $\mathrm{C} 2$-independent mechanisms. Dosedependent C3 deposition was demonstrated when MBL/MASP was added at increasing concentrations (Figure 2), and addition of MBL/MASP plus D and P allowed activation and amplification through the alternative pathway. The impact of the alternative pathway was evident at moderately low MBL/MASP concentrations $(0.2 \mathrm{mg} / \mathrm{l})$. Most likely, this reflected amplification of C4b2amediated $\mathrm{C} 3$ activation. At high MBL/MASP concentrations ( 2 and $20 \mathrm{mg} / \mathrm{l}$ ), amplification was not required in order to obtain pronounced C3 deposition. The assay did not allow assessment of amplification at this level.

No C3 deposition was found when the experiment was repeated in VBS- $\mathrm{Mg}^{2+}$ EGTA with addition of MBL/MASP to the serum at $2 \mathrm{mg} / \mathrm{l}$. We also presensitized the CO-coated wells with MBL/ MASP at $2 \mathrm{mg} / \mathrm{l}$ in VBS and in VBS-EDTA. After washing, the wells were incubated with MBL-deficient serum depleted of C1qDP as well as Igs. No C3 deposition occurred unless the presensitization step was carried out in the presence of $\mathrm{Ca}^{2+}$ (data not shown).

We then examined the potential role of specific antibodies in the MBL-deficient serum. For this purpose, CO-coated wells were presensitized with MBL-deficient serum that was depleted of C1qDP but not of Igs. The serum was diluted in VBS or VBS-EDTA to reach a concentration of $20 \%$, the serum concentration used for subsequent assessment of $\mathrm{C} 3$ deposition. After washing, MBL-deficient serum depleted of C1qDP and Igs was added in combination with purified complement proteins. Addition of $\mathrm{C} 1 \mathrm{q}$ or addition of $\mathrm{D}$ and $\mathrm{P}$ produced efficient $\mathrm{C} 3$ deposition, showing that the classical pathway and the alternative pathway were both capable of supporting antibody-dependent activation. No C3 deposition occurred when the presensitization step was omitted. Identical results were obtained following presensitization in VBS and presensitization in VBS-EDTA (data not shown).

Complement pathway requirements. The kinetic $\mathrm{C} 3$ deposition experiments with PNHS and C2-deficient serum (Figure 1, C and $\mathrm{D}$ ) were repeated in $\mathrm{Mg}^{2+}$ EGTA buffer with the purpose of blocking $\mathrm{Ca}^{2+}$-dependent binding of MBL to the $\mathrm{CO}$ antigen with retention of alternative pathway function. $\mathrm{C} 3$ deposition was reduced to the level found with $\mathrm{BO}$ - or DO-coated wells (data not

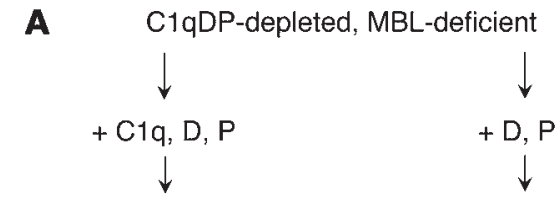

Classical pathway activation (alternative pathway-mediated amplification not required)

Alternative pathway activation
B

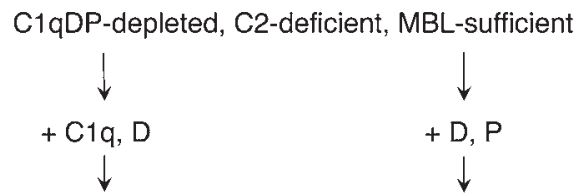

C1q-dependent $\mathrm{C} 2$ bypass (alternative pahtway-mediated amplification required)
MBL-dependent $\mathrm{C} 2$ bypass (alternative pathway-mediated amplification required)
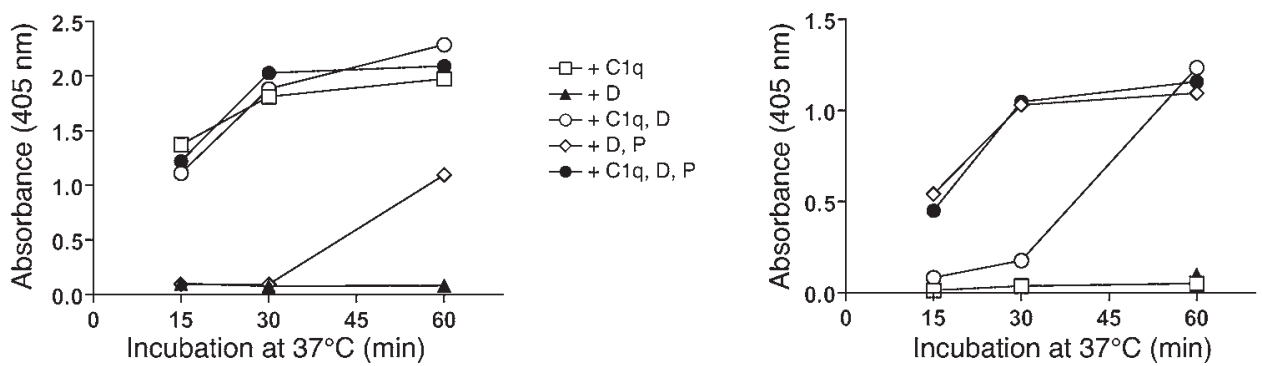

Figure 3

Complement requirements for $\mathrm{C} 3$ deposition induced by $\mathrm{CO}$ antigen (1,000 ng/well). Analysis of MBL-deficient serum (A) and C2-deficient, MBL-sufficient serum (B). The sera were C1qDP depleted and reconstituted with C1q (70 mg/l), D (1 mg/l), and P (25 mg/l) added alone or in combinations. Sera were used at a final concentration of $25 \%$. Interpretations are shown at top. Each experiment was performed in duplicate and was repeated once with similar results. 


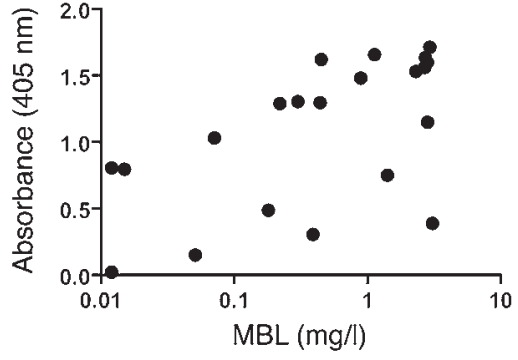

Figure 4

Relationship between MBL concentration and the capacity to support C3 deposition induced by $\mathrm{CO}$ antigen (1,000 ng/well) in C2-deficient sera $(n=21)$. Sera were used at a final concentration of $25 \%$ with incubation at $37^{\circ} \mathrm{C}$ for 30 minutes. The correlation was significant $(P<0.05, r=0.49$, Spearman rank correlation).

shown), providing further evidence for the critical role of MBL binding in the assay.

The kinetic studies were continued using MBL-deficient serum and C2D:18 that were both C1qDP depleted. C2D:18 contained high concentrations of MBL and some antibody to CO (Table 1). The capacity of the sera to support $\mathrm{C} 3$ deposition in the presence of $\mathrm{CO}$ was assessed after substitution with purified C1q, D, and $\mathrm{P}$ added alone or in combinations. Addition of $\mathrm{C} 1 \mathrm{q}$ alone to the MBL-deficient, $\mathrm{C} 1 \mathrm{qDP}$-depleted serum fully restored the capacity to support $\mathrm{C} 3$ deposition, demonstrating classical pathway activation in the absence of a functional alternative pathway (Figure 3A). Selective reconstitution of the alternative pathway by addition of $\mathrm{D}$ and $\mathrm{P}$ resulted in $\mathrm{C} 3$ deposition at a slow rate. We ascribed the efficient classical pathway-mediated activation to the presence of specific antibodies (Table 1). In addition, the antibodies supported alternative pathway activation. It is noteworthy that the alternative pathway-mediated response required a $\mathrm{CO}$ antigen coating dose of $1,000 \mathrm{ng} /$ well and was not seen with a coating dose of $100 \mathrm{ng} /$ well (data not shown).

Results with C2-deficient serum differed sharply from those obtained with MBL-deficient serum. In the C1qDP-depleted, C2deficient serum, $\mathrm{C} 3$ deposition was equally well restored by $\mathrm{D}$ and $\mathrm{P}$ and by C1q, D, and P (Figure 3B). As the serum was MBL sufficient (Table 1), these findings suggested C3 activation by an MBL-dependent $\mathrm{C} 2$ bypass mechanism with requirement of intact alternative pathway function. Addition of $\mathrm{C} 1 \mathrm{q}$ alone had no effect, but a combination of $\mathrm{C} 1 \mathrm{q}$ and $\mathrm{D}$ produced slow $\mathrm{C} 3$ deposition in the serum. In

\section{Figure 5}

Dose-dependent enhancement of $\mathrm{C} 3$ deposition by purified MBL (A), purified MBL/MASP complexes (B), and specific anti-CO IgG antibodies (C) in C2D:21 serum (combined C2 and MBL deficiency). The serum was used at a final concentration of $25 \%$. Shown are experiments in which CO-coated wells $(1,000 \mathrm{ng} /$ well) were presensitized with MBL in VBS before addition of serum $(\mathbf{A})$ and in which MBL/MASP complexes were added directly to the serum (B) applied to the CO-coated wells. In experiments with specific antibodies (C), wells coated with $\mathrm{BO}$ or $\mathrm{CO}$ antigen were presensitized in VBSEDTA with polyclonal IgG (Endobulin) containing defined amounts of the specific antibodies. After washing, incubation of the bound specific antibodies with the C2-deficient serum was carried out at $37^{\circ} \mathrm{C}$ for 30 minutes. Each experiment was performed in duplicate and was repeated once with similar results. this case, C3 activation probably proceeded through the well-known C1q-dependent C2 bypass mechanism triggered by antibodies (29).

Influence of MBL and antibody concentrations in C2-deficient sera. C3 deposition in wells coated with $\mathrm{CO}$ antigen was assessed in the sera of 21 patients with C2 deficiency. The capacity to support C3 deposition in the sera was correlated with concentrations of MBL $(P<0.05$, Spearman rank correlation; Figure 4$)$ but not with the concentrations of specific antibodies (data not shown). Although weak, the correlation indicated that MBL is a major determinant of C3 activation in the assay system. Many factors, including alternative pathway function, are likely to influence the results. C4-deficient serum with a high concentration of MBL $(10 \mathrm{mg} / \mathrm{l})$ also supported efficient $\mathrm{C} 3$ deposition (mean absorbance, 1.4; data not shown). This was probably due to combined effects of high MBL and $\mathrm{B}$ concentrations (Table 1).

Of the 3 C2-deficient sera with undetectable MBL $(<0.015 \mathrm{mg} / \mathrm{l})$, 2 showed moderately high $\mathrm{C} 3$ deposition that could not be readily explained by antibody levels. One C2-deficient patient, C2D:21, demonstrated low concentrations of MBL and anti-CO antibodies (Table 1) and low C3 deposition. This serum was utilized in several of the subsequent experiments.

Reconstitution experiments in serum with combined $C 2$ and MBL deficiency. The serum of C2D:21 provided a useful tool for reconstitution experiments. First, the influence of purified MBL and MBL/ MASP complexes on $\mathrm{C} 3$ deposition onto solid-phase $\mathrm{CO}$ antigen was examined. MBL and MBL/MASP complexes were added to the serum or were used for presensitization of CO-coated wells before addition of serum.
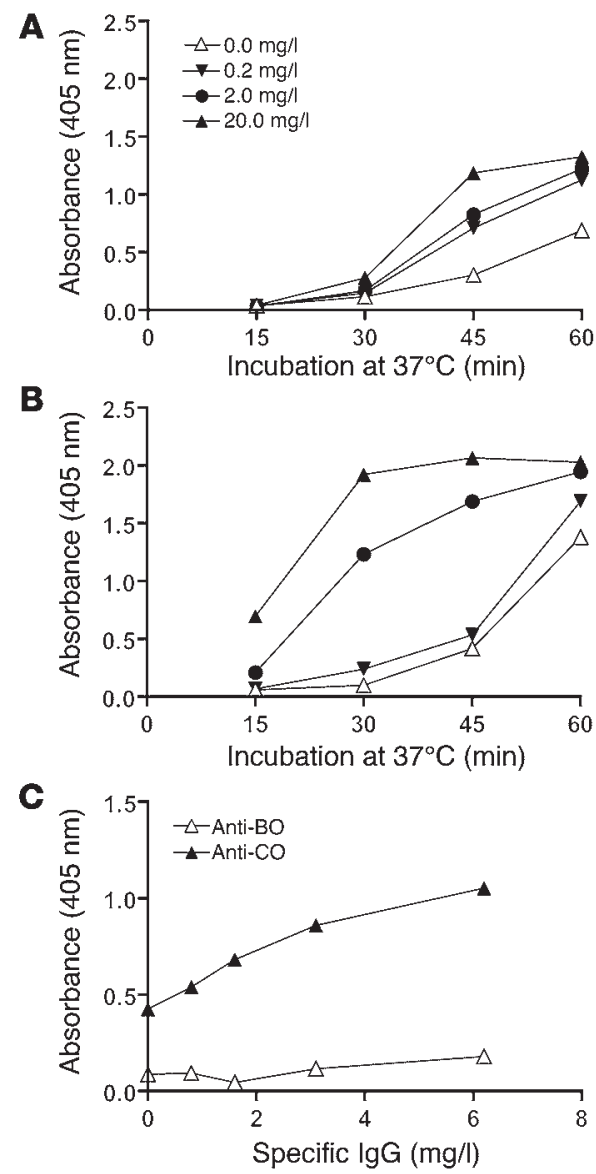


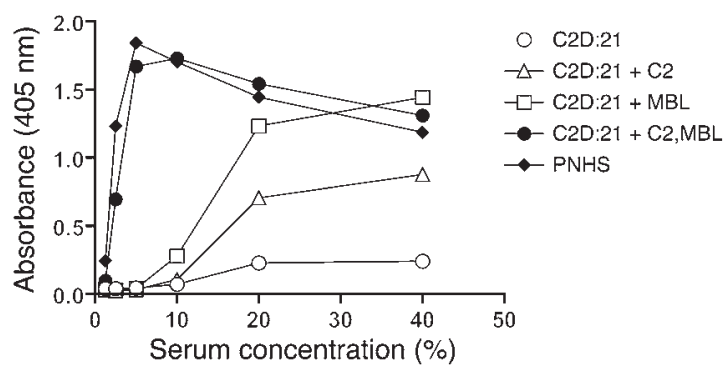

Figure 6

Effect of serum dilution on $\mathrm{C} 3$ deposition induced by $\mathrm{CO}$ antigen (1,000 ng/well) in C2D:21 serum (combined C2 and MBL deficiency). The serum was reconstituted with $\mathrm{MBL}(2 \mathrm{mg} / \mathrm{l})$ and $\mathrm{C} 2(6.5 \mathrm{mg} / \mathrm{l})$ as indicated. PNHS was used as a control. MBL-dependent $\mathrm{C} 2$ bypass activation was abolished in $5-10 \%$ serum. By contrast, these serum concentrations appeared to be optimal for lectin pathway activation mediated through $\mathrm{C} 4 \mathrm{~b} 2 \mathrm{a}$. C3 incubations with serum were carried out at $37^{\circ} \mathrm{C}$ for 30 minutes. The experiment was performed in duplicate and was repeated once with similar results.

Presensitization of CO-coated wells with MBL at the physiological doses of 0.2 and $2.0 \mathrm{mg} / \mathrm{l}$ clearly promoted C3 deposition (Figure 5A). The effect was further enhanced with MBL at $20 \mathrm{mg} / \mathrm{l}$. Similar results were obtained when MBL was added directly to serum before analysis. Addition of MBL/MASP complexes at 2-20 $\mathrm{mg} / \mathrm{l}$ to serum resulted in pronounced $\mathrm{C} 3$ deposition that proceeded at a comparatively fast rate (Figure 5B). Presensitization experiments with MBL/MASP gave similar results (data not shown).

We also examined the effect of specific anti-CO and anti-BO antibodies in a preparation of polyclonal IgG (Endobulin). Microtiter plate wells coated with $\mathrm{CO}$ or $\mathrm{BO}$ antigen were presensitized with defined doses of specific IgG in VBS-EDTA. After washing of the wells, C3 deposition was studied in C2D:21 serum. Anti-CO antibodies supported $\mathrm{C} 3$ deposition in a dose-dependent manner (Figure 5C), but anti-BO antibodies had no effect. Of note, no functional MBL was detected in the Ig preparation.

We then examined the effects of serum dilution on C3 deposition in the presence of CO (Figure 6). Addition of MBL or C2 to C2D:21 serum promoted C3 deposition in $20 \%$ and $40 \%$ serum, but effects in more dilute

\section{Figure 7}

Influence of fractionated MBL/MASP complexes on C3 deposition induced by $\mathrm{CO}$ antigen in the serum of C2D:21. Purified MBL/MASP complexes were separated according to charge and size on a Mono $Q$ column. Elution patterns are shown by Western blot analysis of samples of the fractions as indicated above the blot (2 fractions were combined for application to each slot of the gel). The blot illustrates the differential elution of the MBL oligomers and the elution of the associated MASPs and MAp19. The different MBL oligomers are given as I-IV in order of increasing size (6). The analysis was performed with (open circles) and without (filled circles) reconstitution of the serum with purified C2 (6.5 mg/l). The experiment was repeated once with similar results. serum were negligible. By contrast, the highest $\mathrm{C} 3$ deposition values in PNHS were obtained using 5\% serum. Similar findings were made when C2D:21 serum was reconstituted with a combination of MBL $(2 \mathrm{mg} / \mathrm{l})$ and C2 $(6.5 \mathrm{mg} / \mathrm{l})$. Reconstitution of the serum with $\mathrm{C} 2$ had a very modest effect, indicating that the contribution of antibody-mediated $\mathrm{C} 3$ activation was limited and that the small amount of MBL in the serum did not efficiently support C4b2amediated C3 deposition through the lectin pathway.

Reconstitution with fractionated $M B L / M A S P$ complexes and $M B L$. Purified MBL/MASP complexes were fractionated according to charge and size by chromatography on a Mono Q column (6). Aliquots of the fractions $(1 \mu \mathrm{l})$ were added to C2D:21 serum $(12.5 \mu \mathrm{l})$ in a total volume of $0.05 \mathrm{ml}$ for analysis of their capacity to promote $\mathrm{C} 3$ deposition on CO-coated wells. C3 deposition was determined with fractions corresponding to the position of low-order MBL oligomers (6) and MASP-1 in the first part of the chromatogram (Figure 7).

Reconstitution of C2D:21 serum with C2 before addition of the fractionated MBL/MASP complexes promoted C3 deposition, and the capacity of the fractions to support $\mathrm{C} 3$ deposition then coincided with the whole peak of fractionated MBL/MASP complexes (Figure 7). The peak concentration of eluted MBL (fraction 37) was calculated to yield a final MBL concentration of $1.44 \mu \mathrm{g} / \mathrm{ml}$ in undiluted C2D:21 serum. Thus MBL/MASP complexes were added to serum at fairly modest concentrations.

$M B L$-dependent $C 3$ deposition in the absence of $C 2$ and MASPs. The MBL-deficient serum of C2D:21 was depleted of C1qDP and
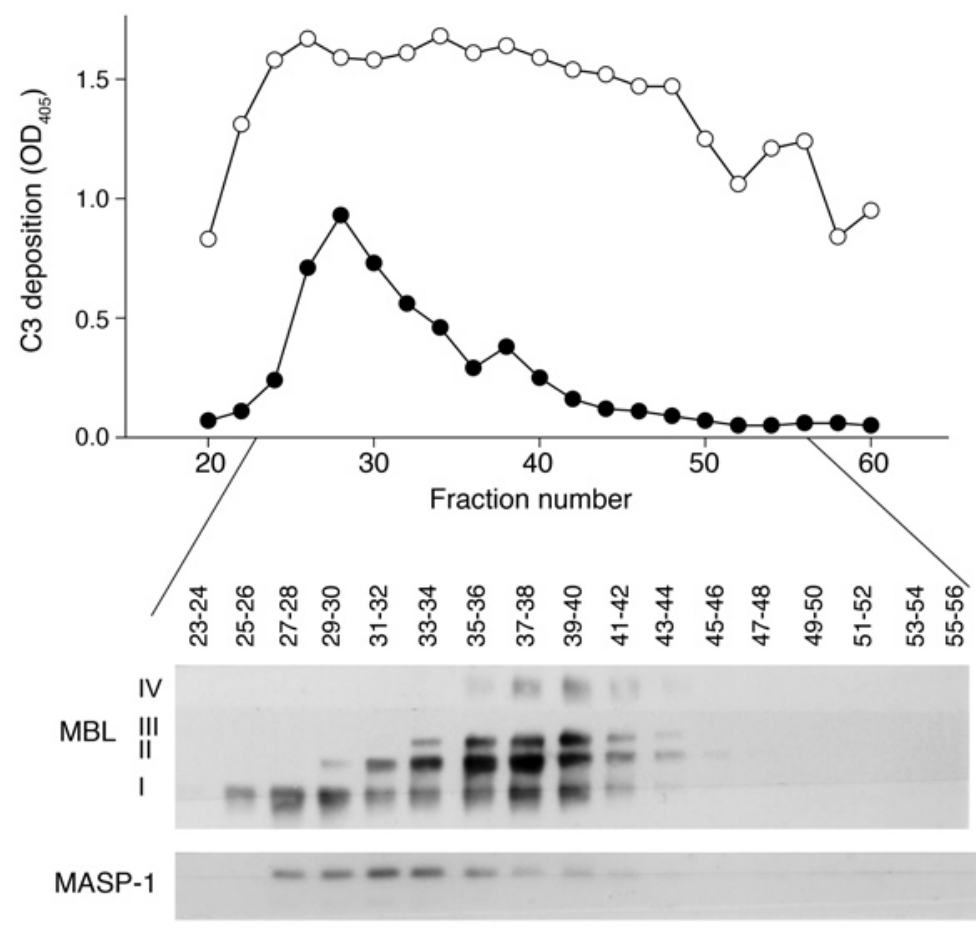

MASP-2 $\quad-\infty-\infty-\infty-$

MAp19

MASP-3 


\section{Table 2}

MBL-dependent C3 deposition through the alternative pathway: lack of requirement for MASP-1, MASP-2, and MASP-3

\begin{tabular}{|c|c|c|c|c|}
\hline \multirow[b]{2}{*}{$\begin{array}{l}\text { Protein } \\
\text { added }^{A}\end{array}$} & \multicolumn{4}{|c|}{ C3 deposition (absorbance at 405 nm) } \\
\hline & $\begin{array}{c}\text { C2D:21 } \\
\text { depleted of } \\
\text { MASP-1, -3B }\end{array}$ & $\begin{array}{c}\text { C2D:21 } \\
\text { depleted of } \\
\text { MASP-2 }\end{array}$ & $\begin{array}{c}\text { C2D:21 } \\
\text { depleted of } \\
\text { MASP-1, }-2,-3^{B}\end{array}$ & $\begin{array}{c}\text { C2D:17 } \\
\text { depleted of MBL; } \\
\text { MASP-1, -2, -3C }\end{array}$ \\
\hline Buffer control & $0.06(0.01-0.15)$ & $0.08(0.04-0.13)$ & & \\
\hline rMBL & $0.11(0.05-0.15)$ & 0.13 & 0.15 & $0.23(0.21-0.24)$ \\
\hline$D, P$ & $0.24(0.15-0.3)$ & 0.14 & 0.14 & $0.20(0.19-0.22)$ \\
\hline rMBL, D, P & $2.1(1.9-2.6)$ & $1.7(1.5-1.9)$ & 1.6 & $1.6(1.5-1.7)$ \\
\hline \multicolumn{5}{|c|}{$\begin{array}{l}\text { ELISA plates coated with CO and sera at final concentrations of about } 25 \% \text { were used. Concentrations of } \\
\text { complement-depleted sera were assessed by measurement of } \mathrm{C} 3, \mathrm{C} 4 \text {, and } \mathrm{C} 5 \text {. The final concentrations } \\
\text { of B in the assay ranged between } 50 \text { and } 70 \mathrm{mg} / \mathrm{l} \text {. Shown are mean and range values obtained in at least } \\
3 \text { experiments. Omission of range indicates that the experiment was performed once. A } \mathrm{rMBL} \text { and purified } \\
\mathrm{D} \text { and } \mathrm{P} \text { were added as indicated at final concentrations of } 1 \mathrm{mg} / \mathrm{l}, 0.25 \mathrm{mg} / \mathrm{l} \text {, and } 6.25 \mathrm{mg} / \mathrm{l} \text {, respectively. } \\
\text { BC2D:21 serum (C2- and MBL-deficient) was depleted of C1qDP. Aliquots were then immunoabsorbed } \\
\text { with anti-MASP-1 and -MASP-3 Sepharose or with anti-MASP-2 Sepharose. Batch-wise immunoabsorp- } \\
\text { tions were carried out once or twice. A third aliquot was immunoabsorbed with anti-MASP-1 and MASP-3 } \\
\text { Sepharose and then with anti-MASP-2 Sepharose. C C2-deficient serum (C2D:17) was depleted of C1qDP. } \\
\text { Aliquots were then depleted of MASP-1 and MASP-3, MASP-2, and MBL by affinity chromatography supple- } \\
\text { mented with batch-wise immunoabsorption. C2-deficient serum (C2D:18) was used as an internal control } \\
\text { (mean, 2.3; range, 1.9-2.6). }\end{array}$} \\
\hline
\end{tabular}

vation. The $\mathrm{C} 2$ bypass mechanism required a serum concentration of at least $20 \%$ and intact alternative pathway function. C4 did not appear to be required. Unlike $\mathrm{CO}$, many natural activators of the lectin pathway may be assumed to activate the alternative pathway. The present findings showed that activation of the MBL-dependent $\mathrm{C} 2$ bypass by solid-phase mannan or mannan-rich LPS of E. coli markedly increased the kinetics of $\mathrm{C} 3$ deposition, which might be highly significant in the course of inflammatory responses.

In more dilute serum, MBL-dependent activation was mediated by $\mathrm{C} 4 \mathrm{~b} 2 \mathrm{a}$ and did not involve the alternative pathway. A recently described lectin pathway assay using mannancoated ELISA plates is strictly C4b2a dependent (31). Under physiological conditions, $\mathrm{C} 4 \mathrm{~b} 2 \mathrm{a}-\mathrm{mediated}$ cleavage of $\mathrm{C} 3$ with amplification through the alternative pathway is likely to be the predominant mechanism for MBL-

MASPs (see Methods). Reconstitution experiments with recombinant MBL (rMBL), D, and $\mathrm{P}$ indicated that CO-induced C3 deposition required $\mathrm{rMBL}$ and a functional alternative pathway and that the activity was independent of MASP-1, -2 , and -3 (Table 2). A confirmatory experiment was performed with the serum of C2D:17. Control experiments using ELISA plates coated with BO or DO antigen gave no $\mathrm{C} 3$ deposition, providing evidence for assay specificity and showing that target binding of rMBL was necessary.

$M B L$-dependent $C 2$ bypass activation by other microbial carbohydrates. C3 deposition in the serum of C2D:21 was examined using mannan-coated ELISA plates and plates coated with mannan-rich LPS from $E$. coli O8, O44, and $\mathrm{O} 77$ strains. In contrast to $\mathrm{CO}$, these carbohydrates were efficient activators of the alternative pathway. Addition of rMBL consistently increased the kinetics of C3 deposition (Figure 8). Partial delipidation of LPS appeared to promote MBL-dependent C2 bypass activation. Similar results were obtained with LPS from E. coli O44 and O77 (data not shown).

\section{Discussion}

O antigen-specific Salmonella oligosaccharides are well-defined microbial antigens $(21,22)$ and were used as solid-phase targets in an ELISA model system for analysis of C3 deposition in serum. CO supported complement activation by several mechanisms, including MBL-dependent recruitment of $\mathrm{C} 4 \mathrm{~b} 2 \mathrm{a}$ through the lectin pathway and antibody-mediated activation of the classical pathway. This is consistent with the recent suggestion that antibody-mediated classical pathway activation partly compensates for MBL deficiency as assessed by studies of mannan antibodies (28). In addition, our analysis provided evidence of alternative pathway-mediated activation of $\mathrm{C} 3$ by specific antibodies and by the C1q-dependent C2 bypass mechanism (29). Polymeric IgA has recently been suggested to activate the lectin pathway (30) and might also have contributed to activation.

The principal finding of the study was the demonstration of a functional MBL-dependent C2 bypass mechanism for C3 acti- dependent complement activation (9). Dose-response experiments demonstrated the importance of alternative pathway-mediated amplification at moderately low MBL concentrations.

The possible contribution of MASPs to MBL-dependent C2 bypass activation of $\mathrm{C} 3$ is a controversial issue. We provided evidence that MASP-1, MASP-2, and MASP-3 are not necessary for $\mathrm{C} 2$ bypass activation of $\mathrm{C} 3$, in accord with previous data showing that cleavage of purified C3 by MASPs is inefficient (13). Moreover, results of fractionation experiments with purified MBL/ MASP complexes argued against a role of MASP-2, since activation of C3 in serum by higher MBL oligomers containing MASP-2 was found to be exclusively $\mathrm{C} 2$ dependent. On the other hand, involvement of MASP-1 cannot be definitely excluded, as fractions containing low-order MBL oligomers and MASP-1 were found to activate $\mathrm{C} 3$ in the absence of $\mathrm{C} 2$. It could be that MASP- 1 recruits other proteases in serum or that cleavage of C 3 by MASP- 1 is more efficient in serum than in the purified system.

Our findings suggested that target-fixed MBL activates the alternative pathway, which we believe to be a novel observation. Thus bound MBL probably provides C $3 \mathrm{~b}$ binding sites that are protected from inactivation by factors $\mathrm{H}$ and $\mathrm{I}$, as previously described for bound IgG (32) and for C4 (33). The question may be raised as to whether $\mathrm{C} 1 \mathrm{INH}$ releases activated MASPs from target-fixed MBL, thereby promoting alternative pathway activation. There is some evidence for $\mathrm{C} 1 \mathrm{INH}$-dependent dissociation of MBL/MASP complexes (34), but this issue has not been fully investigated. $\mathrm{C}_{1} \mathrm{qr}_{2} \mathrm{~s}_{2}$ complexes are known to be dissociated by $\mathrm{C} 1 \mathrm{INH}$ in conjunction with activation $(35,36)$. C3 and C4 form complexes with $\mathrm{C} 1 \mathrm{q}(37)$, indicating a potential for $\mathrm{C} 1 \mathrm{q}-$ mediated activation of the alternative pathway.

It is not known whether the $\mathrm{C} 3$ deposition following addition of $\mathrm{MBL} / \mathrm{MASP}$ to serum (Figure 5B) required complex dissociation that may have delayed responses. Evidently, the kinetics in many of the experiments were slow compared with the kinetics of functions such as alternative pathway-mediated hemolysis at similar serum 

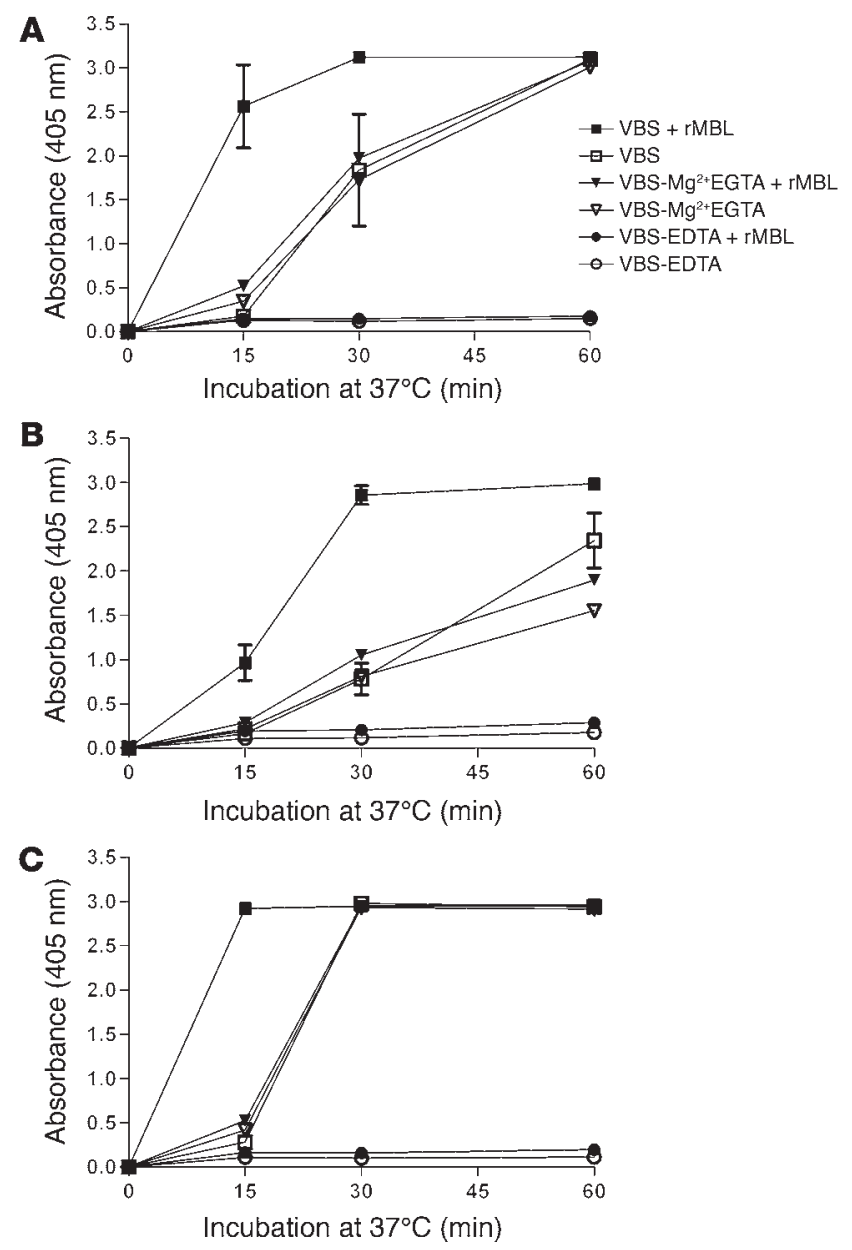

concentrations (27). Most likely, the difference is mainly due to the assay system, as C3 incorporation into solid-phase immune complexes in C2-deficient serum also proceeds at a slow rate as assessed by ELISA (38).

L-ficolin and $\mathrm{H}$-ficolin structurally resemble MBL and bind carbohydrates such as $\mathrm{N}$-acetylglucosamine $(3,8)$. Moreover, L-ficolin was recently shown to be specific for acetyl groups (39). Both recognition proteins form complexes with MASPs and activate the lectin pathway $(3,8)$. The possibility that ficolins are capable of supporting $\mathrm{C} 2$ bypass activation of $\mathrm{C} 3$ and the alternative pathway might be considered, but conclusive analysis of this issue would require reagents that are not currently available.

The complement-activating properties of $\mathrm{BO}, \mathrm{CO}$, and $\mathrm{DO}$ were previously examined by Grossman et al. (22), who showed that sheep erythrocytes coated with $\mathrm{CO}$ produce efficient $\mathrm{C} 3$ breakdown in C4-deficient serum. This provided evidence for alternative pathway activation by the antigen, but did not include analysis of MBL and the lectin pathway. In the study of Schweinle et al. (23), whole Salmonella organisms of the serogroups B, C, and $\mathrm{D}$ were investigated. The bacteria were presensitized with $\mathrm{MBL} /$ MASP complexes and were then investigated for ${ }^{125} \mathrm{I}-\mathrm{C} 3$ deposition in the presence of different sources of complement. Mannose-rich Salmonella serogroup C was reported to activate the alternative pathway through an MBL-dependent mechanism, but the interpretation was not unequivocally supported by the data. One difficulty was that C2-deficient sera and other complement

\section{Figure 8}

MBL-dependent $\mathrm{C} 2$ bypass activation by solid-phase mannan $(\mathbf{A})$ and mannan-rich E. coli O8 LPS (B). The LPS was also used after partial delipidation (C). The LPS coating dose was $0.01 \mathrm{mg} /$ well. $\mathrm{rMBL}$ at 4 $\mathrm{mg} / \mathrm{l}$ was added to C2D:21 serum (combined C2 and MBL deficiency). The experiments were performed using $25 \%$ serum in VBS, VBS$\mathrm{Mg}^{2+} \mathrm{EGTA}$, and VBS-EDTA (see Methods). Mean values of at least 3 experiments are shown together with SEM for experiments with VBS.

sources were used at concentrations (2\%) that would not normally support alternative pathway activation.

Interactions between LPS and the immune system have been intensely studied over the years. Cell-wall LPS from wild-type serum-resistant Gram-negative enteric bacteria such as Salmonella is structurally and functionally composed of 3 parts: the toxic lipid A region, the common core polysaccharide, and the $\mathrm{O}$ antigen-specific polysaccharide (40). With regard to complement, Pillemer et al. (41) originally suggested that LPS activates the properdin system, now known as the alternative pathway, without involvement of antibodies. It was later shown that the classical pathway as well as the alternative pathway is involved in complement activation by LPS, with the polysaccharide part being responsible for alternative pathway activation (42). The present findings emphasize the role of the lectin pathway in antibody-independent complement activation by LPS.

An interesting question concerns the possible impact of $\mathrm{MBL}$ in complement deficiency states. In inherited C4 and C2 deficiencies, concomitant MBL deficiency implies loss of direct MBL-mediated opsonization (43) as well as an impaired capacity to recruit complement. Considerations of this kind may also be relevant in acquired deficiencies of C4 and C2 such as SLE (44). Increased susceptibility to infection has been reported in SLE patients with MBL deficiency (45). MBL-dependent functions might also be important in MASP-2 deficiency, the most recently recognized form of complement deficiency (46).

\section{Methods}

Buffers. The buffers used for this study were as follows: VBS with 0.15 $\mathrm{mmol} / \mathrm{l} \mathrm{Ca}^{2+}$ and $0.5 \mathrm{mmol} / \mathrm{l} \mathrm{Mg}^{2+}$ (VBS); VBS with $10 \mathrm{mmol} / 1 \mathrm{EDTA}$ (VBS-

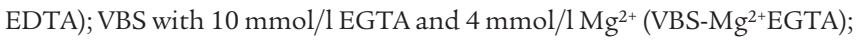
VBS with $0.1 \%$ gelatine (VBSG); PBS with 5 mmol/1 EDTA, pH 7.2 (PBSEDTA); and PBS with $0.05 \%$ Tween (PBS-T).

Oligosaccharide conjugates. Polyacrylamide conjugates of S. typhimurium (serogroup B; O-4,12) SH 4809 octasaccharide, S. thompson (serogroup C; O-6,7) IS 40 decasaccharide, and $S$. enteritidis (serogroup D; O-9,12) SH 1262 octasaccharide were prepared as described by Chernyak et al. (21).

Other carbohydrates. Mannan-coated ELISA plates were kindly provided by Wieslab AB. We also examined LPS from 3 mannose-rich $E$. coli strains, E. coli $\mathrm{O} 8$ (47), E. coli $\mathrm{O} 44$ (48), and E. coli O77 (49).

Partially delipidated LPS (LPS-OH) was prepared by de-O-acylation of ester-linked fatty acids from the lipid A with $0.25 \mathrm{M} \mathrm{NaOH}$ at $37^{\circ} \mathrm{C}$ for 16 hours. After centrifugation, $\mathrm{pH}$ was adjusted to 3.5 , and free fatty acids were removed by repeated extractions with $\mathrm{CHCl}_{3}$. After adjustment of $\mathrm{pH}$ to 7.0, the LPS-OH was extensively dialyzed against distilled water (48 hours at $4^{\circ} \mathrm{C}$ ) and lyophilized.

Purified proteins. MBL, MBL/MASP complexes, and C2 were isolated according to previously described procedures $(6,11)$, as were C1q, D, and P (27) and C3 (50). MBL/MASP complexes were further fractionated by ion exchange chromatography on a Mono Q column (Amersham Pharmacia) as previously described (6). The rMBL used in some of the experiments 
was produced as previously described (51). Complement proteins were mostly determined by electroimmunoassay (52). In some experiments, C2 was measured by hemolytic assay (53). Concentrations of C1q, D, P, B, C2, and $\mathrm{C} 3$ were given in $\mathrm{mg} / \mathrm{l}$ assuming that the pooled reference serum used contained C1q at $70 \mathrm{mg} / \mathrm{l}, \mathrm{D}$ at $1 \mathrm{mg} / \mathrm{l}, \mathrm{P}$ at $25 \mathrm{mg} / \mathrm{l}, \mathrm{B}$ at $200 \mathrm{mg} / \mathrm{l}$, and $\mathrm{C} 2$ at $26 \mathrm{mg} / \mathrm{l}$ (54). A commercial calibrator (Dako) was used for Ig measurements. Human purified IgG, Endobulin (Baxter), was used as source of specific anti-BO and anti-CO antibodies and was a gift from Immuno. MASP-1 and MASP-3 were measured by ELISA using a monoclonal antibody against the common heavy chain of the proteins (55). MASP-2 was also determined by ELISA (56).

Measurement of specific antibodies and MBL. Specific IgM and IgG antibodies to $\mathrm{BO}, \mathrm{CO}$, and $\mathrm{DO}$ were measured by ELISA according to a procedure that allowed expression of the concentrations in $\mathrm{mg} / \mathrm{l}(25)$. IgA antibodies were rarely found. MBL concentrations were determined with a sandwich ELISA (57), in which microtiter plates (Nunc-Immunoplates Maxisorp; Nunc) were coated with mouse monoclonal anti-MBL (clone 131-1, IgG1к; Immunolex Therapeutics). Control wells were coated with another mouse IgG1א monoclonal antibody. Biotinylated mouse monoclonal anti-MBL (Immunolex Therapeutics) followed by enzyme-labeled streptavidin (Streptavidine AP, D0396; Dako) was used for detection. Values were given in weight units using an MBL standard serum for calibration (Immunolex Therapeutics). In some experiments, biotinylated mouse monoclonal anti-MBL was used together with enzyme-labeled streptavidin for measurement of MBL binding to ELISA microtiter plate wells coated with BO, CO, or DO.

$M B L$ genotyping. Analysis of MBL haplotypes was performed largely as described by Steffensen et al. (19), with identification of the structural wild-type allele $A$, the mutant alleles $B, C$, and $D$, and the promoter region haplotypes $H Y, L Y$, and $L X$.

Serum and serum reagents. All sera were stored in aliquots at $-80^{\circ} \mathrm{C}$. The complement-deficient sera used in the study included sera from 21 patients with C2 deficiency type I (24) and 1 patient with complete C4 deficiency (26). Blood sampling was performed after informed consent was provided, within the framework of projects approved by the Lund University Research Ethics Committee (LU 350-93, LU 513-01). PNHS from 17 healthy blood donors was used as a control. A unit of fresh frozen serum, purchased from the Blood Bank of the University Hospital of Lund, was incidentally found to be MBL deficient (MBL $<0.015 \mathrm{mg} / \mathrm{l}$ ). The MBL deficiency was confirmed (MBL $0.005 \mathrm{mg} / \mathrm{l}$ ) by time-resolved immunofluorometric assay (58).

Sera from previously reported (24) C2-deficient patients C2D:17, C2D:18, and C2D:21 and the MBL-deficient serum were depleted of the complement proteins C1q, D, and P (27). The C1qDP-depleted, MBLdeficient serum was further depleted of Igs by affinity chromatography using protein LG-Sepharose (58) followed by affinity chromatography using rabbit anti- $\kappa$ and anti- $\lambda$ antibodies (Dako) coupled to cyanogen bromide-activated (CNBr-activated) Sepharose 4B (Amersham Biosciences). The concentrations of IgG, IgA, and IgM in the Ig- and C1qDP-depleted MBL-deficient serum were less than $20 \mathrm{mg} / 1,5 \mathrm{mg} / \mathrm{l}$, and $30 \mathrm{mg} / \mathrm{l}$, respectively, as determined by immunochemical methods. Concentrations in the sera of MBL, IgM anti-CO antibodies, and IgG anti-CO antibodies as well as the MBL genotypes of the donors are summarized in Table 1.

C2D:21 had a combined C2 and MBL deficiency (Table 1). After C1qDP depletion, the serum was further depleted of MASPs. For immunoabsorption of MASP-1 and MASP-3, the monoclonal antibodies 1E2 and $2 \mathrm{~B} 11(11,55)$ and 2D3 were coupled to CNBr-activated Sepharose beads (Amersham Biosciences). Monoclonal antibodies to MASP-2 (56) were coupled to CNBr-activated Sepharose in the same fashion. Control beads with mouse IgG were also prepared. Immunoabsorptions were carried out according to a batch-wise procedure, wherein $1 \mathrm{ml}$ of C1qDP-depleted C2D:21 serum in VBS was added to an equal volume of sedimented Sepharose beads in sealed tubes that were rotated end over end at $4^{\circ} \mathrm{C}$ for 18 hours. After sedimentation of the beads, the immunoabsorbed serum was collected. The serum was centrifuged at $2,000 \mathrm{~g}$ for 15 minutes to remove remaining particles and was then frozen at $-80^{\circ} \mathrm{C}$. The beads were washed and were then eluted with Tris/ $\mathrm{HCl}, \mathrm{pH} 2.8$. After single immunoabsorptions the sera contained less than about $2 \%$ of the original MASP- 3 and MASP-2 concentrations. One aliquot of C1qDP-depleted C2D:21 serum was immunoabsorbed twice in order to ensure complete removal of MASP-1 and MASP-3, and another aliquot was immunoabsorbed twice to remove MASP-2. A third aliquot was immunoabsorbed once with anti-MASP-1 and anti-MASP-3 Sepharose and once with anti-MASP-2 Sepharose. Treatment of serum with control Sepharose beads coupled to mouse IgG did not influence MASP concentrations.

To confirm results with C2D:21 serum, the C1qDP-depleted serum of C2D:17 (Table 1) was also depleted of MASP-1, -2 , and -3 and of MBL. Aliquots of the serum $(1 \mathrm{ml})$ in VBS at $4{ }^{\circ} \mathrm{C}$ were sequentially passed through three $1-\mathrm{ml}$ affinity chromatography columns containing (a) anti-MASP-1 and anti-MASP-3 Sepharose, (b) anti-MASP-2 Sepharose, and (c) mannan-Sepharose (11). The pooled preparations contained trace amounts of MASP-3 (1-2\%). For this reason, immunoabsorption with anti-MASP-1 and anti-MASP-3 Sepharose was repeated once using the batch-wise procedure.

C3 deposition assay. C3 deposition was assessed by ELISA. Microtiter plates (Nunc-Immunoplates Maxisorp; Nunc) were coated with BO, CO, or DO antigen in $50 \mathrm{mmol} / \mathrm{l}$ carbonate buffer, $\mathrm{pH} 9.5$, overnight at $4^{\circ} \mathrm{C}$. The coating dose was $1,000 \mathrm{ng} /$ well unless otherwise specified. Three wells were used for each sample, 2 coated wells and 1 uncoated well. After washing with PBS, all wells were blocked with VBSG for 2 hours at room temperature. After washing with PBS and VBS, sera diluted in VBS were added to each of the 3 wells at $0.05 \mathrm{ml} /$ well. The plates were incubated at $37^{\circ} \mathrm{C}$ in a thermoblock (Techne) for 15-60 minutes and were then washed with PBS-T. Rabbit anti-C3c antibodies (Dako) conjugated (59) with alkaline phosphatase (Type VII-T; Sigma-Aldrich) were added at $0.05 \mathrm{ml} /$ well. This antibody has previously been shown to react with C3, C3b, iC3b, and $\mathrm{C} 3 \mathrm{c}$, but not with $\mathrm{C} 3 \mathrm{dg} / \mathrm{d}$ in ELISA and immunoblotting systems (60). After incubation at room temperature for 2 hours, the plates were washed with PBS-T. The reaction was visualized by adding $0.05 \mathrm{ml} /$ well of $p$-nitrophenylphosphate $(1 \mathrm{~g} / 1$; Sigma-Aldrich) in $10 \%$ diethanolamine, $\mathrm{pH}$ 9.8. After 30 minutes' incubation in the dark at room temperature, the enzymatic reaction was measured at $405 \mathrm{~nm}$ in a Multiskan Plus photometer (Labsystems). Control sera were included for adjustment of interassay variation. C3 deposition was expressed as the mean absorbance in the duplicate oligosaccharide-coated wells with subtraction of the background absorbance in the uncoated well. In a few supplemental experiments, the $\mathrm{C} 3$ protein remaining in supernatants of oligosaccharide-coated wells and control wells was measured by electroimmunoassay in order to further assess C3 deposition.

Reconstitution experiments. In the reconstitution experiments, the concentrations of purified proteins added were expressed according to the concentrations in undiluted serum. When a single dose of purified protein was used, the concentration usually approximated the mean physiological concentration (100\%). In some experiments C1q and C2 were used at lower concentrations (10-20\% of normal) based on titrations indicating that these concentrations were not limiting in the assays. When complementdepleted sera were used, the dilutions were adjusted so as to achieve the serum protein concentrations obtained with diluted whole serum. In some experiments, reconstitution of function was achieved by presensitization procedures. For presensitization of oligosaccharide-coated ELISA plate 
wells, recognition proteins (MBL or antibodies) were added to the wells for 30-60 minutes at room temperature in $\mathrm{Ca}^{2+}$-containing VBS or VBSEDTA. After extensive washing of the wells, serum reagents were added for investigation of $\mathrm{C} 3$ deposition.

Statistics. Correlation was assessed with the Spearman rank correlation test. A $P$ value less than 0.05 was considered significant.

\section{Acknowledgments}

This work was supported by grants from the Swedish Medical Research Council (project numbers 7921, 12631, and 15092), the Danish Medical Research Council, the European Union (QLG1-CT-2001-01039), the University Hospital of Lund, the Crafoord Foundation, the Swedish Rheumatism Association, the Swedish Society for Medical Research, the Royal Physiographic Society in Lund, King Gustaf V's 80th Birthday Fund, and the Foundations of Greta and Johan Kock, Nanna Svartz, Clas Groschinsky, Åke Wiberg, Anna-Lisa and Sven-Erik Lundgren, and Alfred Österlund.

Received for publication June 16, 2005, and accepted in revised form February 7, 2006.

Address correspondence to: Anders G. Sjöholm, Clinical Microbiology and Immunology, University Hospital of Lund, Sölvegatan 23, SE-221 85 Lund, Sweden. Phone: 46-46-173281; Fax: 46-46189117; E-mail: anders.sjoholm@med.lu.se.
1. Turner, M.W., and Hamvas, R.M. 2000. Mannosebinding lectin: structure, function, genetics and disease associations. Rev. Immunogenet. 39:305-322.

2. Hoffmann, J.A., Kafator, F.C., Janeway, C.A., Jr., and Ezekowitz, R.A.B. 1999. Phylogenetic perspectives in innate immunity. Science. 284:1313-1318.

3. Holmskov, U., Thiel, S., and Jensenius, J.C. 2003 Collectins and ficolins: humoral lectins of the innate immune defense. Annu. Rev. Immunol. 21:547-578

4. Matsushita, M., and Fujita, T. 1992. Activation of the classical complement pathway by mannosebinding protein in association with a novel C1slike serine protease. J. Exp. Med. 176:1497-1502.

5. Thiel, S., et al. 1997. A second serine protease associated with mannan-binding lectin that activates complement. Nature. 386:506-510.

6. Dahl, M.R., et al. 2001. MASP-3 and its association with distinct complexes of the mannan-binding lectin complement activation pathway. Immunity. 15:127-135

7. Stover, C.M., et al. 1999. Two constituents of the initiation complex of the mannan-binding lectin activation pathway of complement are encoded by a single structural gene. J. Immunol. 162:3481-3490.

8. Matsushita, M., and Fujita, T. 2002. The role of ficolins in innate immunity. Immunobiology. 205:490-497.

9. Suankratay, C., Zhang, X.-H., Chang, Y., Lint, T.F., and Gewurz, H. 1998. Requirement for the alternative pathway as well as C4 and C2 in complement-dependent hemolysis via the lectin pathway. J. Immunol. 160:3006-3013.

10. Walport, M.J. 2001. Complement. First of two parts. N. Engl. J. Med. 344:1058-1066.

11. Matsushita, M., Thiel, S., Jensenius, J.C., Terai, I., and Fujita, T. 2000. Proteolytic activities of two types of mannose-binding lectin-associated serine protease. J. Immunol. 165:2637-2642.

12. Rossi, V., et al. 2001. Substrate specificieties of recombinant mannan-binding lectin-associated serine proteases-1 and -2. J. Biol. Chem. 276:40880-40887.

13. Ambrus, G., et al. 2003. Natural substrates and inhibitors of mannan-binding lectin-associated serine protease- 1 and -2 : a study on recombinant catalytic fragments. J. Immunol. 170:1374-1382.

14. Vorup-Jensen, T., et al. 2000. Distinct pathways of mannan-binding lectin (MBL)- and C1-complex autoactivation revealed by reconstitution of $\mathrm{MBL}$ with recombinant MBL-associated serine protease-2. J. Immunol. 165:2093-2100.

15. Matsushita, M., and Fujita, T. 1995. Cleavage of the third component of complement (C3) by mannosebinding protein-associated serine protease (MASP) with subsequent complement activation. Immunobiology. 194:443-448.

16. Yu, C.Y. 1998. Molecular genetics of the human MHC complement gene cluster. Exp. Clin. Immunogenet. 15:213-230.
17. Figueroa, J.E., and Densen, P. 1991. Infectious diseases associated with complement deficiencies. Clin. Microbiol. Rev. 4:359-395.

18. Pickering, M.C., Botto, M., Taylor, P.R., Lachmann, P.J., and Walport, M.J. 2001. Systemic lupus erythematosus, complement deficiency, and apoptosis. Adv. Immunol. 76:227-324.

19. Steffensen, R., Thiel, S., Varming, K., Jersild, C., and Jensenius, J.C. 2000. Detection of structural gene mutations and promoter polymorphisms in the mannan-binding lectin (MBL) gene by polymerase chain reaction with sequence-specific primers. J. Immunol. Methods. 241:33-42.

20. Madsen, H.O., et al. 1995. Interplay between promoter and structural gene variants control basal serum level of mannan-binding protein. J. Immunol. 155:3013-3020.

21. Chernyak, A., Weintraub, A., Norberg, T., and Kallin, E. 1990. Preparation of oligosaccharide-polyacrylamide conjugates and their use as antigens in enzyme immunoassay (EIA). Glycoconj. J. 7:111-120.

22. Grossman, N., Svensson, S.B., Leive, L., and Lindberg, A.A. 1990. Salmonella O-antigen-specific oligosaccharide-octyl conjugates activate complement via the alternative pathway at different rates depending on the structure of the O-antigen. Mol. Immunol. 27:859-865.

23. Schweinle, J.E., Ezekowitz, R.A.B., Tenner, A.J., Kuhlman, M., and Joiner, K.J. 1989. Human mannose-binding protein activates the alternative complement pathway and enhances serum bactericidal activity on a mannose-rich isolate of Salmonella. J. Clin. Invest. 84:1821-1829.

24. Jönsson, G., et al. 2005. Hereditary C2 deficiency in Sweden. Frequent occurrence of invasive infection, atherosclerosis and rheumatic disease. Medicine (Baltimore). 84:23-34.

25. Selander, B., et al. 1999. Low concentrations of immunoglobulin G antibodies to Salmonella serogroup C in C2 deficiency: suggestion of a mannanbinding lectin pathway-dependent mechanism. Scand. J. Immunol. 50:555-561.

26. Nordin Fredriksson, G., et al. 1998. Characterization of non-expressed $\mathrm{C} 4$ genes in a case of complete C4 deficiency: identification of a novel point mutation leading to a premature stop codon. Hum. Immunol. 59:713-719.

27. Sjöholm, A.G., Selander, B., Östenson, S., Holmstöm, E., and Söderström, C. 1991. Normal human serum depleted of $\mathrm{C} 1 \mathrm{q}$, factor $\mathrm{D}$ and properdin: its use in studies of complement activation. APMIS. 99:1120-1128.

28. Roos, A., et al. 2004. Antibody-mediated activation of the classical pathway of complement may compensate for mannose-binding lectin deficiency. Eur. J. Immunol. 34:2589-2598.

29. Knutzen Steuer, K.L., et al. 1989. Lysis of sensitized sheep erythrocytes in human sera deficient in the second component of complement. J. Immunol. 143:2256-2261.
30. Roos, A., et al. 2001. Human IgA activates the complement system via the mannan-binding lectin pathway.J. Immunol. 167:2861-2868.

31. Seelen, M.A., et al. 2005. Functional analysis of the classical, alternative, and MBL pathways of the complement system: standardization and validation of a simple ELISA. J. Immunol. Methods. 296:187-198.

32. Fries, L.F., Gaither T.A., Hammer, C.H., and Frank, M.M. 1984. C3b covalently bound to IgG demonstrates a reduced rate of inactivation by factors $\mathrm{H}$ and I. J. Exp. Med. 160:1640-1655.

33. Meri, S., and Pangburn, M.K. 1990. A mechanism of activation of the alternative complement pathway by the classical pathway: protection of $\mathrm{C} 3 \mathrm{~b}$ from inactivation by covalent attachment to C4b. Eur. J. Immunol. 20:2555-2561.

34. Petersen, S.V., et al. 2000. Control of the classical and the MBL pathway of complement activation. Mol. Immunol. 37:803-811.

35. Cooper, N.R. 1985. The classical complement pathway: activation and regulation of the first complement component. Adv. Immunol. 37:151-207.

36. Laurell, A.-B., Mårtensson, U., and Sjöholm, A.G. 1987. C1 dissociation. Spontaneous generation in human serum of a trimer containing $\mathrm{C} 1$ inactivator, activated C1r, and zymogen C1s. J. Immunol. 139:4145-4151.

37. Wouters, D., et al. 2005. Complexes between C1q and C3 or C4: novel and specific markers for classical complement pathway activation. J. Immunol. Methods. 298:35-45.

38. Junker, A., et al. 1998. Binding of properdin to solid-phase antigen-antibody complexes: critical role of the classical activation pathway of complement. Scand. J. Immunol. 47:481-486.

39. Krarup, A., Thiel, S., Hansen, A., Fujita, T., and Jensenius, J.C. 2004. L-ficolin is a pattern recognition molecule specific for acetyl groups. J. Biol. Chem. 279:47513-47519.

40. Wiese, A., Brandenburg, K., Ulmer, A.J., Seydel, U., and Müller-Loennies, S. 1999. The dual role of lipopolysaccharide as effector and target molecule. Biol. Chem. 380:767-784.

41. Pillemer, L., Schoenberg, M.D., Blum, L., and Wurz, L. 1955. Interaction of the properdin system with polysaccharides. Science. 122:545-549.

42. Vukajlovich, S.W., Hoffman, J., and Morrison, D.C. 1987. Activation of human serum complement by bacterial lipopolysaccharides: structural requirements for antibody independent activation of the classical and alternative pathway. Mol. Immunol. 24:319-331.

43. Kuhlman, M., Joiner, K., and Ezekowitz, A.B. 1989. The human mannose-binding protein functions as an opsonin. J. Exp. Med. 169:1733-1745.

44. Sturfelt, G., and Sjöholm, A.G. 1984. Complement components, complement activation and the acute phase response in systemic lupus erythematosus. Int. Archs. Allergy Appl. Immunol. 75:75-83. 
45. Garred, P., et al. 1999. Mannose-binding lectin polymorphisms and susceptibility to infection in systemic lupus erythematosus. Arthritis Rheum. 42:2145-2152.

46. Stengaard-Pedersen, K., et al. 2003. Inherited deficiency of mannan-binding lectin-associated serine protease 2. N. Engl. J. Med. 349:554-560.

47. Jansson, P.E., et al. 1985. Structural studies of the $\mathrm{O}$-antigen polysaccharides of Klebsiella $\mathrm{O} 5$ and Escherichia coli O8. Carbohydr. Res. 45:59-66.

48. Staaf, M., Widmalm, G., Weintraub, A., and Nataro, J.P. 1995. Structural studies of the O-antigenic polysaccharide from Escherichia coli O44:H18. Eur. J. Biochem. 233:473-477.

49. Yildirim, H., Weintraub, A., and Widmalm, G. 2001. Structural studies of the O-polysaccharide from the Escherichia coli O77 lipopolysaccharide. Carbobydr. Res. 333:179-183.

50. Tack, B.J., and Prahl, J.W. 1976. Third component of human complement: purification from plasma and physicochemical characterization. Biochemistry. 15:4513-4521.

51. Vorup-Jensen, T., et al. 2001. Recombinant expression of human mannan-binding lectin. Int. Immunopharmacol. 1:677-687.

52. Johnson, U., Truedsson, L., and Gustavii, B. 1983. Complement components in 100 newborns and their mothers determined by electroimmunoassay. Acta Pathol. Microbiol. Immunol. Scand. (C). 91:147-150.

53. Ngan, B-Y., Gelfand, E.W., and Minta, J.O. 1977. A simple one-step hemolytic assay for $\mathrm{C} 2$ with $\mathrm{C} 2$ deficient human serum. J. Immunol. 118:736-741.

54. Cooper, N.R. 1988. Laboratory investigation of complement proteins and complement receptors. Baillieres Clin. Immunol. Allergy. 2:263-293.

55. Terai, I., Kobayashi, K., and Fujita, T. 1997. Human serum mannose-binding lectin (MBL)-associated serine protease-1 (MASP-1): determination of levels in body fluids and identification of two forms in serum. Clin. Exp. Immunol. 110:317-323.

56. Møller-Kristensen, M., et al. 2003. Levels of mannanbinding lectin-associated serine protease- 2 in healthy individuals. J. Immunol. Methods. 282:159-167.

57. Sjöholm, A.G., Truedsson, L., and Jensenius, J.C. 2001. Complement pathways and meningococcal disease. Diagnostic aspects. In Meningococcal disease. Methods and protocols. A.J. Pollard and M.C.J. Maiden, editors. Humana Press. Totowa, New Jersey, USA. 529-547.

58. Kihlberg, B.-M., Sjöholm, A.G., Björck, L., and Sjöbring, U. 1996. Protein LG - a powerful immunoglobulin-binding hybrid protein. Eur. J. Biochem. 240:556-563.

59. Voller, A., Bidwell, D.E., and Bartlett, A. 1976. Enzyme immuno-assays in diagnostic medicine. Bull. World Health Organ. 53:55-65.

60. Lund, E.D., Sørensen, L.S., and Brandslund, I. 1990. Specificities of monoclonal antibodies against the C3d split product. Complement Inflamm. 7:18-29. 